\title{
Retraction Note: Use of a new method for determining the vulnerability and risk of pollution of major groundwater reservoirs in the region of Annaba-Bouteldja (NE Algeria)
}

Badra Attoui ${ }^{1} \cdot$ Nacer Kherici $^{1}$.

Houria Kherici-Bousnoubra ${ }^{1}$

Published online: 19 April 2015

(C) Springer-Verlag Berlin Heidelberg 2015

Retraction to: Environ Earth Sci (2014)

72:891-903

DOI 10.1007/s12665-013-3012-9

The article is retracted at the publisher's request because it was previously published under the title "State of vulnerability to pollution of the big reservoirs of ground water in the region of Annaba-Bouteldja (NE Algeria)" in the journal of Geographia Technica (2012), No 2, 1-13, by the same authors.

The online version of the original article can be found under doi:10.1007/s12665-013-3012-9.

Badra Attoui

att.badra@yahoo.fr

Nacer Kherici

nacer.kherici@univ-annaba.org

Houria Kherici-Bousnoubra

houria.kherici@univ-annaba.org

1 Geology Laboratory, Earth Sciences Faculty, University

of Annaba, El Hadjar, B.O:12, Annaba, Algeria 